Review

\title{
Aripiprazole Lauroxil, a Novel Injectable Long-Acting Antipsychotic Treatment for Adults with Schizophrenia: A Comprehensive Review
}

\author{
Kunal Maini ${ }^{1}$, Haley Gould ${ }^{2}$, Jessica Hicks ${ }^{2}$, Fatima Iqbal ${ }^{2}$, James Patterson II ${ }^{1}$, Amber N. Edinoff ${ }^{1, *}$,

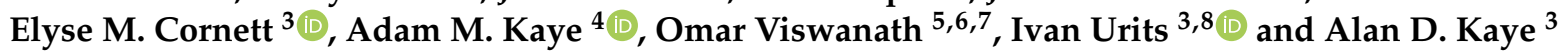 \\ 1 Department of Psychiatry, Louisiana State University Shreveport, Shreveport, LA 71103, USA; \\ kmaini@lsuhsc.edu (K.M.); JPatte@lsuhsc.edu (J.P.II) \\ 2 Shreveport School of Medicine, Louisiana State University, Shreveport, LA 71103, USA; \\ hgoul1@lsuhsc.edu (H.G.); jhick6@lsuhsc.edu (J.H.); fiqba2@lsuhsc.edu (F.I.) \\ 3 Department of Anesthesiology, Louisiana State University Shreveport, Shreveport, LA 71103, USA; \\ ecorne@lsuhsc.edu (E.M.C.); ivanurits@gmail.com (I.U.); alan.kaye@lsuhs.edu (A.D.K.) \\ 4 Department of Pharmacy Practice, Thomas J. Long School of Pharmacy and Health Sciences, \\ University of the Pacific, Stockton, CA 95211, USA; akaye@PACIFIC.EDU \\ 5 College of Medicine-Phoenix, University of Arizona, Phoenix, AZ 85004, USA; viswanoy@gmail.com \\ 6 Department of Anesthesiology, Creighton University School of Medicine, Omaha, NE 68124, USA \\ 7 Valley Anesthesiology and Pain Consultants—Envision Physician Services, Phoenix, AZ 85004, USA \\ 8 Beth Israel Deaconess Medical Center, Department of Anesthesiology, Critical Care, and Pain Medicine, \\ Harvard Medical School, Boston, MA 02215, USA \\ check for \\ updates \\ * Correspondence: Amber.edinoff@lsuhs.edu; Tel.: +1-318-675-8969
}

Citation: Maini, K.; Gould, H.; Hicks, J.; Iqbal, F.; Patterson, J., II; Edinoff, A.N.; Cornett, E.M.; Kaye, A.M.; Viswanath, O.; Urits, I.; et al. Aripiprazole Lauroxil, a Novel Injectable Long-Acting Antipsychotic Treatment for Adults with Schizophrenia: A Comprehensive Review. Neurol. Int. 2021, 13, 279-296. https://doi.org/10.3390/ neurolint13030029

Academic Editor: Tibor Hortobagyi

Received: 14 May 2021

Accepted: 21 June 2021

Published: 1 July 2021

Publisher's Note: MDPI stays neutral with regard to jurisdictional claims in published maps and institutional affiliations.

Copyright: (c) 2021 by the authors. Licensee MDPI, Basel, Switzerland. This article is an open access article distributed under the terms and conditions of the Creative Commons Attribution (CC BY) license (https:// creativecommons.org/licenses/by/ $4.0 /)$.
Abstract: Purpose of Review. This is a comprehensive review of the literature regarding the use of Aripiprazole lauroxil for schizophrenia. This review presents the background, evidence, and indications for using aripiprazole lauroxil to treat schizophrenia in the context of current theories on the development of schizophrenia. Recent Findings. Schizophrenia is a chronic mental health disorder that currently affects approximately 3.3 million people in the United States. Its symptoms, which must be present for more than six months, are comprised of disorganized behavior and speech, a diminished capacity to comprehend reality, hearing voices unheard by others, seeing things unseen by others, delusions, decreased social commitment, and decreased motivation. The majority of these symptoms can be managed with antipsychotic medication. Aripiprazole lauroxil is a long-acting intramuscular injection that works as a combination of partial agonist activity at $\mathrm{D}_{2}$ and $5-\mathrm{HT}_{1 \mathrm{~A}}$ receptors combined with antagonist activity at 5- $\mathrm{HT}_{2 \mathrm{~A}}$ receptors. It can be dosed as a 4-, 6-, or 8-week injection, depending on oral dosage. Aripiprazole lauroxil was FDA approved in October of 2015. Summary. Schizophrenia is a severe psychiatric disorder if left untreated. There are multiple medications to help treat schizophrenia. One antipsychotic agent, aripiprazole lauroxil, offers long duration injections that optimize and improve compliance. Known side effects include weight gain, akathisia, neuroleptic malignant syndrome, tardive dyskinesia, and orthostatic hypotension. Aripiprazole lauroxil is an FDA-approved drug that can be administered monthly, every six weeks, or every two months and has been shown to be both safe and effective.

Keywords: schizophrenia; schizophrenia treatment; aripiprazole lauroxil; long-acting injections; aristada

\section{Introduction}

Schizophrenia is a psychotic disorder that can be characterized as having positive symptoms, negative symptoms, and cognitive dysfunction. Positive symptoms consist of the presence of behaviors or thoughts that are not typically present, such as psychosis, delusions, hallucinations, disorganized speech, and behavior [1]. Negative symptoms are characterized by social withdrawal, flat affect, anhedonia, and low energy [1]. The positive 
and negative symptoms of schizophrenia are thought to be a result of dopaminergic dysregulation. Cognitive impairment is also a main component in schizophrenia and is largely refractory to treatment [2]. Cognitive deficits include impairment in attention, working memory, episodic memory, processing speed, and executive function [3]. A decline in social and cognitive functions generally presents itself $>10$ years before the onset of psychotic symptoms and leads to those with schizophrenia encountering problems with their ability to maintain social relationships, employment, and independence [3,4]. Although treatment with antipsychotics and psychosocial interventions can help increase quality of life, the severity of negative symptoms and cognitive impairment at onset can be a determining factor in treatment efficacy [5]. The Diagnostic and Statistical Manual of Mental Disorders 5th edition requires that psychotic symptoms be present for over six months [6]. The lifetime prevalence of major depression in schizophrenia was found to be between $30-50 \%$ [7,8]. 34\% of patients were found to have a lifetime diagnosis of alcohol abuse or dependence [9].

The treatment of schizophrenia is a combination of antipsychotic medications and nonpharmacological treatment [10]. The combination of pharmacological and nonpharmacological interventions can result in improvement in psychiatric symptoms, social functioning, quality of life, and treatment retention, as well as reducing the need for hospitalizations and crisis services, legal system involvement, self-harm, and substance abuse [10]. First-generation antipsychotics (FGAs) such as haloperidol have been proven to be effective; however, adverse effects such as Parkinsonism and tardive dyskinesia are a hindrance to long-term use [10]. Second-generation antipsychotics (SGAs) are thought to have equal or better efficacy than first-generation antipsychotics. SGAs are also more useful in the treatment of negative symptoms; however, SGAs can have harmful adverse effects on the cardiovascular (QT prolongation) and endocrine systems (hyperprolactinemia, which can cause sexual dysfunction, amenorrhea, galactorrhea and bone demineralization) [10]. An important aspect of treating a patient with schizophrenia is "patient-level characteristics" that can impact the outcomes of interventions [10].

\section{Epidemiology}

A meta-analysis found that the median estimate of the core incidence of schizophrenia is 15.2 per 100,000 [11]. The incidence rate ratio between males and females was found to be 1.4 [11]. The incidence ratio of schizophrenia varied significantly between migrants and native-born individuals, with the ratio being 4.6 migrant-to-native-born [11]. The incidence of urban and mixed urban-rural was found to be 19 and 13.3 per 100,000, respectively [11]. The median lifetime prevalence was 4.0 per 1000 , and the lifetime morbid risk was 7.2 per 1000 [11].

\section{Pathophysiology}

It is hypothesized that schizophrenia occurs in individuals with a genetic predisposition to the disease, with environmental factors that over time lead to the progression of schizophrenia [12]. Adoption studies of individuals adopted within three days of birth show that the incidence of schizophrenia is the same in both the adopted subjects and those who stay with their biological family [13]. This suggests that environmental triggers in those with a genetic predisposition to schizophrenia occur sometime between conception and birth in the form of epigenetic changes are thought to be one of the main reasons for alter gene expression [14].

Serotonin plays an important role in cortical development and regulation in cognition, mood, and impulse control; as a result, it is hypothesized that abnormal serotonergic activity can contribute to the pathophysiology of schizophrenia [15,16]. Studies have shown that a reduction in the serotonin 2A receptor (HTR2A), as well as HTR7, is implicated in the pathogenesis of schizophrenia $[17,18]$. Neuroimaging data also suggest that levels of HTR2A may vary at different stages of the disorder [19]. Regulating the levels of HTR2A may also provide a new opportunity for treatment options [20]. 
Acetylcholine controls the cholinergic system in the central nervous system (CNS) and plays an important role in both learning and memory [21]. There are five different types of muscarinic receptors, all of which are differentially expressed throughout the CNS [22]. The variable roles of each type of muscarinic receptor and their respective distribution can help shed light on the pathophysiology of schizophrenia [20]. Low levels of the M1 receptor (CHRM1), in particular, have been implicated in the pathogenesis of schizophrenia $[23,24]$. The emergence of microarray technology has allowed researchers to track gene expression changes, including presynaptic functioning, G protein signaling, and myelination, all of which can have implications in both diagnosing and treating schizophrenia $[20,25,26]$.

\section{Risk Factors}

The development of schizophrenia has been largely based on the neurodevelopmental theory [27]. The neurodevelopmental theory is based on a "single-hit" theory [28,29]. In the neurodevelopment theory, it is hypothesized that brain dysconnectivity is derived from deficits in dendritic spines during development arising from a combination of genetic factors and obstetric complications [30,31]. These deficits may progress further, leading to the expression of psychotic symptoms as a result of neuromaturation events such as aggressive synaptic pruning, or elevated cortisol leading to dendritic atrophy [28,32-35].

At present, it is thought that the pathogenesis of schizophrenia is not related to a "single hit," rather it is the combination of "vulnerability factors" that alone have a weak individual effect but act together at critical points of neurodevelopment, which ultimately leads to schizophrenia [27]. These "vulnerability factors" include cannabis use, childhood trauma, and social defeat, among others [27]. Longitudinal studies suggest that there is up to a $40 \%$ greater risk of psychosis among people who have used cannabis [36,37]. It is thought that adolescents who use cannabis experience the onset of their first psychotic episode 2.7 years earlier than those with no history of cannabis use [38]. Childhood trauma including physical abuse, emotional abuse, sexual abuse, parental loss or divorce, parental substance abuse, poverty, and social defeat are thought to be vulnerability factors for the later development of schizophrenia [39]. Meta-analyses suggest that those with a history of childhood trauma have a risk of developing schizophrenia that is three times as high as those with no history of such trauma [40]. A history of childhood trauma also appears to be associated with worse positive symptoms as well as non-remission of positive symptoms [41]. Social defeat is defined as "losing a confrontation amongst any type of hostile dispute amongst humans" and consists of the stressors faced while being a part of a marginalized or excluded social or ethnic group [27]. Some studies suggest that the risk of schizophrenia is highest amongst immigrant groups who experience low social integration, poverty, alienation, and social uprooting [42].

\section{Presentation}

Schizophrenia presents a diverse combination of signs and symptoms, including distortions in perception, cognitive impairments, motor abnormalities, avolition and apathy, communication difficulties, and restricted affective expression, all of which are classified as being either positive, negative, cognitive, disorganized, mood or motor symptoms [43]. Positive symptoms include impaired reality testing with the presence of delusions, hallucinations, and reality distortions. Reality distortions indicate the formal onset of schizophrenia [43]. The positive symptoms of schizophrenia are likely a result of dopaminergic mesolimbic hyperactivity [44]. Negative symptoms involve the blunting of affect, which includes loss of motivation, poverty of speech, inability to experience pleasure, and lack of interest [45-47]. Negative symptoms can be further divided into primary and secondary negative symptoms $[47,48]$. Primary "deficit syndrome" negative symptoms are intrinsic to schizophrenia, while secondary negative symptoms are caused by extrinsic factors such as environmental deprivation and depression [43]. In contrast to the negative symptoms of schizophrenia, patients can also exhibit increased emotional reactivity [43]. The pathophysiology of the negative symptoms of schizophrenia is not well understood, and the 
symptoms are largely refractory to treatment $[44,49,50]$. Disorganized thought refers to the fragmentation of the logical, progressive, and goal-oriented nature of normal thought, which can range from mild circumstantiality to fully incoherent speech in the form of "word salad" [51]. Disorganized thought also includes derailment, clanging, and neologisms as well as poverty of thought [43]. Formal thought disorder often co-occurs with disorganized behavior [43]. Depression is present in the majority of schizophrenia patients, is more severe in those with substance abuse disorder, can occur in any phase of the disease, and significantly contributes to disease burden [52-55]. Along with positive and negative symptoms, schizophrenia also has cognitive impairment [56,57]. Cognitive impairments include impairments of episodic memory [58-60], processing speed [61], verbal fluency [62], attention [63,64], executive functions and working memory [65-68].

\section{Current Treatment of Schizophrenia}

There are many effective treatments available for schizophrenia, but patients experience repeated relapses related to nonadherence with oral medication formulations. The use of long-acting injectable (LAI) antipsychotics for patients who are unable to maintain a steady medication regimen is beneficial in reducing rehospitalization and treatment failure [69]. The current therapies available for schizophrenia are based on the dopamine hypothesis, which attributes positive symptoms to increased dopamine in the mesolimbic pathway and negative symptoms to decreased dopamine in the mesocortical pathway [70]. The dopamine $\mathrm{D}_{2}$ receptor is the primary target for drugs to alleviate psychotic symptoms, but it is associated with elevations in prolactin and extrapyramidal side effects. The currently used antipsychotic drugs fully or partially block the effects of dopamine at the $\mathrm{D}_{2}$ receptor [71]. Dopamine exerts its effects through G-protein coupled receptors that are further divided into the $D_{1}$ subtype $\left(D_{1}\right.$ and $D_{5}$ receptors) and $D_{2}$ subtype $\left(D_{2}, D_{3}\right.$, and $D_{4}$ receptors) [72,73]

\subsection{First- and Second-Generation Antipsychotics}

The first-generation antipsychotics block mostly $\mathrm{D}_{2}$ receptors in the brain and do not show any selectivity for the dopamine pathways present in the CNS, which leads to unwanted side effects associated with these antipsychotic drugs such as elevated prolactin and extrapyramidal symptoms [70]. First-generation drugs, such as haloperidol and chlorpromazine, have clinical efficacy in reducing the positive symptoms and decreasing the risk of relapse; however, they have little to no benefit for negative symptoms or the cognitive impairment associated with schizophrenia. Second-generation antipsychotics, such as clozapine and risperidone, are less likely to cause extrapyramidal symptoms (but both medications have other side effects that patients should be made aware of) and are efficacious in treating both positive symptoms and negative symptoms. Neither first nor second generation is superior at treating the cognitive deficits and achieves only moderate improvement in cognition when dosed properly [71]. Second-generation drugs and longacting injectable formulations of antipsychotics have been associated with greater treatment efficacy. Specifically, long-acting injectables are more beneficial for patients with poor oral medication compliance. A cohort study conducted in 2017 by Tiihonen et al. determined that clozapine and long-acting injectable drugs like paliperidone are more effective at reducing the risk of treatment failure and rehospitalization than other antipsychotic drugs. Long-acting injectables have a $20-30 \%$ lower risk of rehospitalization compared with oral drugs [74].

\subsection{Third-Generation Antipsychotics}

While first- and second-generation antipsychotics are antagonists at the $\mathrm{D}_{2}$ receptor, third-generation antipsychotics are either partial $\mathrm{D}_{2}$ agonists or biased ligands. Thirdgeneration antipsychotics such as aripiprazole, cariprazine, lumateperone, and brexpiprazole are the newest group of antipsychotics. Since third-generation drugs have been introduced, patients' risk of experiencing parkinsonian symptoms, akathisia, and dystonia 
is substantially lower than with other antipsychotic agents. In general, patients that are only on third-generation drugs have had lower side effects.

There is still variability in patient response with any class of antipsychotic drugs. Some patients respond better to the older group of drugs, while others benefit more from a newer class of drugs, but this can be dependent on prescriber preference or comfort of use [70]. Even with the increasing number of antipsychotic drugs available to treat schizophrenia, management of the disease is far from optimal. Antipsychotic drugs have limitations that include patients lacking response to drug treatment, not controlling negative symptoms or cognitive defects, a wide range of debilitating side effects, and potential decreased survival due to pro-arrhythmic effects. Clozapine is the drug of choice for patients who are classified as "treatment-resistant" but has the potential to cause fatal agranulocytosis, as well as constipation (leading to bowel obstruction), severe cardiovascular issues and seizures. [70]. With the development of newer antipsychotics, the focus of treatment for schizophrenia has shifted from relieving the psychotic/positive symptoms to alleviating the negative symptoms and cognitive decline that affects the patient's ability to recover and integrate back into society [75].

\section{Aripiprazole Lauroxil Drug Information}

\subsection{Dosing Information}

Aripiprazole lauroxil is an FDA-approved atypical antipsychotic indicated for the treatment of schizophrenia. Aripiprazole lauroxil can only be administered by intramuscular (IM) injection (deltoid $441 \mathrm{mg}$ only or gluteal region $441 \mathrm{mg}, 662 \mathrm{mg}, 882 \mathrm{mg}, 1064 \mathrm{mg}$ ) from a licensed healthcare professional. This method nullifies the need for daily oral administration and will help improve adherence to treatment in patients who are nonadherent with taking daily medications [76]. If a patient has never taken aripiprazole, oral tolerability must be established before aripiprazole lauroxil can be administered [77]. The half-life of oral aripiprazole is approximately $75 \mathrm{~h}$, and it may take 2 weeks for some patients to reach tolerability status [78]. Oral dosage reflects how much injection dosage is given. If the patient were taking $10 \mathrm{mg}$ per day, then they would receive a $441 \mathrm{mg}$ injection every month. If the patient were taking $15 \mathrm{mg}$ per day, then they would receive $662 \mathrm{mg}$ every month, $882 \mathrm{mg}$ every 6 weeks or $1064 \mathrm{mg}$ every 2 months. If the patient were receiving $20 \mathrm{mg}$ or higher, then they would receive a $882 \mathrm{mg}$ injection every month. Oral aripiprazole should be administered for 21 consecutive days after the first aripiprazole lauroxil injection. The patient should be counseled on adverse reactions and side effects of the medication and counseled to go to the emergency room. Aripiprazole lauroxil can be given as a monthly dose of $441 \mathrm{mg}$, $662 \mathrm{mg}$, or $882 \mathrm{mg}$ based on the needs of the patient. These doses are equal to $300 \mathrm{mg}$, $450 \mathrm{mg}$, and $600 \mathrm{mg}$ of aripiprazole, respectively. All doses should be administered in the gluteal muscle except for the $441 \mathrm{mg}$ dose, which can be given in the deltoid muscle dependent on patient preference $[77,79]$.

\subsection{Contraindications and Adverse Effects}

Aripiprazole lauroxil is contraindicated in patients with a known hypersensitivity reaction to aripiprazole and is not approved for the treatment of elderly patients with dementia-related psychosis (boxed warning). Aripiprazole lauroxil is also associated with other adverse effects, including cerebrovascular accidents, neuroleptic malignant syndrome, tardive dyskinesia, hyperglycemia, dyslipidemia, orthostatic hypotension, leukopenia/neutropenia, seizures, cognitive and/or motor impairment, hyperthermia, and dysphagia [77]. Patients with a history of leukopenia or neutropenia should be monitored for the first few months of therapy and receive regular complete blood counts to ensure a normal white blood cell level. There is not sufficient data to determine the risks of birth defects or miscarriage in pregnant women using aripiprazole lauroxil, but withdrawal symptoms and extrapyramidal side effects have been observed in infants exposed to antipsychotics during the third trimester [80]. 


\section{Mechanism of Action}

Aripiprazole lauroxil is a prodrug of aripiprazole and is administered as an intramuscular injection. Once administered, aripiprazole lauroxil is first converted to $\mathrm{N}$ hydroxymethyl aripiprazole by enzyme-mediated hydrolysis and is hydrolyzed again to aripiprazole $[81,82]$. Aripiprazole was originally reported to be a partial agonist at $\mathrm{D}_{2}$ and $5 \mathrm{HT}_{1 \mathrm{~A}}$ receptors, with a combination of antagonistic activity at $5 \mathrm{HT}_{2 \mathrm{~A}}$ receptors $[77,82]$. At present, it has been demonstrated that aripiprazole can act as an antagonist, partial agonist, or full agonist at $\mathrm{D}_{2}$ receptors [82]. Antagonistic activity at alpha $\mathrm{1}_{1}$ receptors explains some of the adverse reactions that have been reported, such as orthostatic hypotension [83]. Contrary to other second-generation antipsychotics, aripiprazole displays a higher affinity for the dopamine receptor than the serotonin receptor. When the extracellular concentration of dopamine is high, such as in the mesolimbic circuit, aripiprazole can compete with dopamine as a partial antagonist. If the extracellular dopamine concentration is low, namely in dopamine circuits involved in cognition and working memory, aripiprazole can bind and partially activate other dopamine receptors. This unique mechanism of action gives aripiprazole the name "dopamine stabilizer" as it should ideally maintain dopamine levels in the tuberoinfundibular and nigrostriatal pathways to avoid hyperprolactinemia and extrapyramidal side effects [70,75]. Aripiprazole is also a partial agonist for $D_{2}$ receptor-mediated recruitment of the $\beta$-arrestin- 2 signaling pathway. This pathway appears to be critical in minimizing extrapyramidal side effects while maintaining antipsychotic efficacy [82]. Targeting the $\beta$-arrestin signaling pathways is promising in the design of future antipsychotic drugs [70].

\section{Pharmacokinetics and Pharmacodynamics}

\subsection{Absorption and Distribution}

After injection of aripiprazole lauroxil, aripiprazole is released into the systemic circulation after 5-6 days, and maximum concentration is reached approximately 41 days after administration. To bridge the gap created by slow absorption into the systemic circulation, patients should take oral aripiprazole for 21 days following the first injection [69]. An alternative regimen consisting of a nano-crystalline milled version of aripiprazole lauroxil and a $30 \mathrm{mg}$ single dose of oral aripiprazole achieved the desired therapeutic dose in the same time frame as a $441 \mathrm{or} 882 \mathrm{mg}$ injection plus the 21-day oral initiation regimen [79]. Following absorption, aripiprazole displays broad extravascular distribution and has a volume of distribution of $268 \mathrm{~L}$ [83].

\subsection{Metabolism}

Once injected, aripiprazole lauroxil dissolves slowly and is cleaved by esterases into $\mathrm{N}$-hydroxymethyl aripiprazole and lauric acid, which is a fatty acid found in human breast and cow's milk. Through water-mediated hydrolysis, N-hydroxymethyl aripiprazole becomes aripiprazole and formaldehyde. The amount of formaldehyde formed by the metabolism of aripiprazole lauroxil is a minute amount compared with the amount produced by basic metabolism and a regular diet [69]. Aripiprazole lauroxil undergoes metabolism in the liver by CYP3A4 and CYP2D6 to dehydro-aripiprazole $[69,83]$. Pharmacokinetic differences may be present in individuals who are poor metabolizers of CYP2D6, and healthcare providers may need to adjust the dose based on patient response to treatment [80].

\subsection{Elimination}

The mean elimination half-life of aripiprazole lauroxil after administration of the final dose of $441 \mathrm{mg}, 882 \mathrm{mg}$, and $1064 \mathrm{mg}$ ranges from 53.9 to 57.2 days. Similar to the other long-acting injectables available, aripiprazole lauroxil has an extended pharmacokinetic profile due to an elimination rate that is faster than the absorption rate [84]. Thus, the calculated half-life for the injection of aripiprazole lauroxil is greater than the half-life of oral aripiprazole, which has a mean of $75 \mathrm{~h}$ [77]. After aripiprazole lauroxil is converted 
into its active metabolite, there is no measurable amount of prodrug present, making it unlikely that the rate of conversion or distribution of aripiprazole lauroxil is the cause of the slow elimination rate [84].

\section{Clinical Studies: Safety and Efficacy 10.1. Phase I Studies}

A randomized, open-label, single-dose study evaluated the bioavailability and safety of AL in adult patients with schizophrenia. Forty-six patients were randomized into two groups; 441-mg IM injection administered at the deltoid site or gluteal site. Although deltoid administration resulted in higher values for both areas under the plasma concentrationtime curve from time zero to the last quantifiable plasma concentration (AUClast) and maximum plasma concentration (Cmax) of aripiprazole and dehydro-aripiprazole, the range of exposures overlapped for the two sites. Moreover, 38 of the 46 patients experienced at least one TEAE, which were all mild or moderately intense and did not lead to any discontinuations. The most common $\mathrm{AE}$ was injection-site pain, which occurred at a higher frequency with deltoid administration (63.6\%) than gluteal administration (better absorption) (27.3\%) [85].

A 44-week, open-label study evaluated the pharmacokinetics and safety of 1064-mg AL in patients with schizophrenia by randomizing 105 patients to one of three groups; 1064-mg dosed every 8 weeks, 882-mg dosed every 6 weeks, and 441-mg dosed every 4 weeks for a total of 4, 5 and 7 injections. Overall, 1064-mg AL provided similar mean aripiprazole concentrations to $882-\mathrm{mg} \mathrm{AL}$, with both resulting in higher aripiprazole exposure than 442-mg AL. Injection-site pain was the most frequent $\mathrm{AE}$ in all three regimens, with the overall incidence of injection-site reactions of $11.5 \%$. Although most AEs were mild or moderate, severe AEs (SAEs) occurred in all 3 groups but, with the exception of one case of increased psychosis, were considered unrelated to AL. The incidence of discontinuation due to TEAEs was $2.9 \%, 11.8 \%$ and $5.7 \%$ in the $1064-\mathrm{mg}, 882-\mathrm{mg}$ and $441-\mathrm{mg}$ groups, respectively. The incidence of AEs associated extrapyramidal symptoms (EPS) was the highest in the 882-mg group [86].

\subsection{Phase III Studies}

A 12-week, randomized, double-blind, placebo-controlled study (RDBPC) demonstrated the safety and efficacy of two doses of Aripiprazole Lauroxil (AL) in treating patients with schizophrenia experiencing an acute relapse. Patients were randomized to AL 441-mg, AL 882-mg or placebo, with a dosing regimen of every 4 weeks, administered in the gluteal muscle. Outcomes studied were an improvement from baseline to day 85 in Positive and Negative Syndrome Scale (PANSS) total score and the Clinical Global Impressions-Improvement scale (CGI-I) score at day 85 for AL groups compared with placebo. The placebo-adjusted least-squares mean differences of PANSS total score for AL 441-mg and AL 882-mg were - $10.9(1.8)(p<0.001)$ and -11.9 (1.8) $(p<0.001)$. The CGI-I scores for both AL groups were also significantly better than the placebo (Wilcoxon rank sum test: $p<0.001$ ). The incidence of severe TEAEs was similar in all three groups, with insomnia, akathisia, headache, and anxiety common TEAEs. Akathisia was observed to have an incidence in the AL groups twice that of the placebo group, the only TEAE to reach this. The overall incidence of injection-site reactions was low, and pain was the most common injection-site reaction. The rate of discontinuation due to AEs was $6.8 \%, 2.9 \%$, and $17.9 \%$ for the $441-\mathrm{mg}, 882-\mathrm{mg}$, and placebo groups, respectively [87].

Nasrallah et al. carried out a 52-week, open-label extension study of the 12-week RDBPC [87] to assess changes in endocrine and metabolic parameters due to AL monotherapy in outpatients with schizophrenia. For the whole population, there was a decrease in serum prolactin levels, slight decreases in levels of total cholesterol and triglycerides, and slight increases in fasting blood glucose, $\mathrm{HbA1c}$, and body weight. No clinically meaningful difference was found for these parameters between the two treatment arms (AL 441-mg and $882-\mathrm{mg}$ ). The incidence of TEAEs was similar in both groups, with insomnia, increased 
weight and anxiety TEAEs. The rate of discontinuation due to AEs as well as the incidence of SAEs were both higher in the 882-mg group [88].

\subsection{Phase IV Studies}

A prospective, 6-month, open-label study evaluated clinical outcomes and the safety of switching to AL from paliperidone palmitate (PP) and risperidone long-acting injection (RLAI) in 51 patients with schizophrenia who did not tolerate the latter or did not see improvement in symptoms. Both Clinical Global Impressions-Severity (CGI-S) and Brief Psychiatric Rating Scale (BPRS) scores showed statistically significant improvements at the end of treatment period and after 6 months, respectively. Moreover, the overall retention rate was $68.6 \%$, and the incidence of discontinuation due to medication-related reasons was $<10 \%$. The incidence of any AE was $41.2 \%$, any SAE was $9.8 \%$, and of drug-related AEs was $17.6 \%$. Common AEs included psychotic disorder (7.8\%), anxiety $(5.9 \%)$ and suicidal ideation (5.9\%) [89].

\subsection{Other Studies}

A series of post-hoc analyses of the phase 3, 12-week RDBPC [87] were performed and are described below.

Potkin et al. carried out a subgroup analysis to evaluate the efficacy and safety of AL treatment for patients who had severe psychotic symptoms (defined as having a PANSS total score greater than the median score of 92). A mixed model for repeated measures (MMRM) showed statistically significant decreases in placebo-adjusted mean change in PANSS total score and PANSS Positive, Negative, and General Psychopathology scores for both AL $441 \mathrm{mg}$ and AL $882 \mathrm{mg}$. The overall responder rates for both AL doses were also significantly higher compared with placebo: $49 \%(p<0.001)$ and $61 \%$ $(p<0.001)$, respectively. Finally, effect sizes for this subgroup of patients were higher for both doses than for the group of patients with less severe symptoms (defined as PANSS $\leq 92$ ). Moreover, AL- $882 \mathrm{mg}$ resulted in a higher responder rate and also produced a higher effect size in the more severely ill patient subgroup than the AL 441-mg. Akathisia, headache, insomnia, and anxiety were among common AEs in the patient subgroup analyzed [90].

Targum et al. analyzed the effect of age and gender on the treatment response of AL versus placebo. For the analysis, patients were stratified into the following age groups: $<30,30-39,40-49$, and 50-69 years. ANCOVA analysis showed no significant interaction effects between age and treatment for both AL $441 \mathrm{mg}$ versus placebo and AL $882 \mathrm{mg}$ versus placebo; $(\mathrm{F}=0.27 ; p=0.60)$ and $(\mathrm{F}=0.92 ; p=0.34)$, respectively. Odds ratios (ORs) for treatment response rates, (response defined as $\geq 30 \%$ total PANSS score improvement from baseline) on day 85 also showed higher association for either AL dose versus placebo for all age groups. No interaction effect between gender and treatment was observed, with outcomes for both men and women being better in both AL groups than placebo [91].

Correll et al. assessed social and functional outcomes using 6- and 4-item Positive and Negative Syndrome Scale (PANSS) Prosocial subscales and Personal and Social Performance (PSP) total score. Statistically significant improvements were observed in both 6and 4-item PANSS Prosocial Scores for both doses of AL versus placebo, with the treatment effect sizes with AL $441 \mathrm{mg}$ versus placebo being Cohen's d = 0.52 and AL $882 \mathrm{mg}$ versus placebo being Cohen's $d=0.49$. PSP total score results also showed a similar trend, with a statistically significant increase for both doses versus placebo, with treatment effect sizes of Cohen's d = 0.51 and 0.59 for AL 441-mg or AL 882-mg compared with placebo, respectively [92].

Citrome et al. analyzed the effectiveness of AL using the number needed to harm $(\mathrm{NNH})$ and the number needed to treat (NNT). Pooled AL results (using both AL 441-mg and 882-mg results) produced NNT values of 4, 6, 10 and 26 when the response thresholds were $\geq 20 \%, \geq 30 \%, \geq 40 \%$, and $\geq 50 \%$ decrease in PANSS total score from baseline to day 85 , respectively. A Cohen's d of 0.61 (95\% CI: 0.44-0.79) for the PANSS total score change and 
an NNH of -8 (95\% CI: -6 to -15$)$ for discontinuation due to AEs were both calculated for pooled doses of AL versus placebo. Moreover, some AEs produced a statistically significant estimate of double-digit $\mathrm{NNH}$ values for pooled AL doses versus placebo, including akathisia, toothache, increased blood creatine phosphokinase, and increased weight [93].

Nasrallah et al. analyzed the effect of AL on metabolic and endocrine parameters such as body weight, glycemic control, and lipid and prolactin levels. At day 85, in both AL groups relative to placebo, mean body weight increased slightly while prolactin levels decreased in both men and women. Changes in lipid parameters (total cholesterol, LDL cholesterol, and triglycerides), plasma glucose, and $\mathrm{HbA} 1 \mathrm{c}$ were insignificant. The overall incidence of AEs related to metabolic effects was low and was $2.4 \%, 1.4 \%$, and $2.4 \%$ in AL $441 \mathrm{mg}$, AL $882 \mathrm{mg}$, and placebo groups, respectively [94].

Citrome et al. also analyzed the effect of AL on agitation and hostility levels of patients with schizophrenia using three outcomes: PSP disturbing and aggressive behavior domain, PANSS Hostility item (P7) score in the subpopulation with a PANSS Hostility item P7 score of more than 1 at baseline, and the PANSS excited component (PANSS-EC) score. Significant improvements occurred for all three outcomes: $(p<0.05)$ for reduction in PANSS Hostility item P7 score for the subpopulation treated with 882-mg, $p<0.001$ for mean change in PANSS-EC scores for both groups versus placebo, and $p=0.007$ and $p<0.001$ for reduction of incidence of PSP disturbing and aggressive behavior domain for AL $441 \mathrm{mg}$ vs. placebo and AL $882 \mathrm{mg}$ vs. placebo, respectively. Additionally, greater benefits with AL 882-mg were indicated because it showed a significant reduction in the mean PANSS Hostility item P7 score in the subpopulation, even after controlling for positive symptoms and somnolence or akathisia, thus producing a specific anti-hostility effect, and also showed greater improvement than AL 441mg group for PANSS-EC [95].

McEvoy et al. carried out an analysis of the 52-week extension study [88] to evaluate the durability of long-term AL treatment in a subgroup population (patients who had completed both the initial 12-week study and the subsequent 52-week study and were randomized to either the AL 441-mg group or 882-mg group in the extension study). For both AL groups, a statistically significant decrease occurred for both PANSS total score and CGI-S scores from week 12 to week 64 . By week 64 , remission rates were $73.8 \%$ and $68.1 \%$ in the $441 \mathrm{mg}$ and $882 \mathrm{mg}$ groups, respectively, with the median remission time from the beginning of the 12 weeks being 16.1 and 16.4 weeks, respectively. Rates of treatment discontinuation were low for the $441 \mathrm{mg}$ (27.25) and $882 \mathrm{mg}$ (34\%) groups in the extension study, with withdrawal due to adverse events being $2.5 \%$ and $5 \%$, respectively [96].

Moreover, a targeted systematic review of 31 RCTs (7 primary studies and 24 posthoc analyses) compared LAIs to placebo, oral antipsychotics (OAPs) and other LAIs. AL was among the LAIs included. Results showed that LAIs were wholly superior to placebo and partly superior to OAPs regarding prevention of relapse and hospitalization, with no observed differences in comparison to other LAIs. LAIs were comparable to OAPs in other domains such as all-cause discontinuation, functioning, quality of life, and tolerability and were associated with higher patient satisfaction and service engagement. Moreover, although results from recent meta-analyses were inconclusive, they did not show an advantage for OAPs over LAIs [97]. Table 2 summarizes the studies discussed in this section.

\subsection{Comparison Study}

A network meta-analysis (NMA) carried out an indirect comparison between AL and paliperidone palmitate (PP) using data from four Phase III clinical trials. Results demonstrated that all four effective-treatment arms (AL $441 \mathrm{mg}$ and $882 \mathrm{mg}$; and PP $156 \mathrm{mg}$ and $234 \mathrm{mg}$ ) showed effectiveness by reductions in PANSS total score versus placebo. The extent of these reductions was similar, with the range of mean differences spanning from -8.12 to -12.01 , with overlapping $95 \%$ credible intervals. These results, in addition to a 
similar incidence of TEAEs for both AL and PP, supported the finding that AL and PP were equally efficacious [98].

A study evaluated the differences in the steady-state aripiprazole plasma concentrations of two long-acting injectable (LAI) formulations of aripiprazole: aripiprazole once-monthly $400 \mathrm{mg}$ (AOM 400) and AL. The outcomes measured were the median minimum plasma concentration at steady state $(\mathrm{Cmin}, \mathrm{ss})$, calculated based on observations from previous clinical trials, and the average plasma concentration at steady state (Cavg,ss), based on simulations. Cavg,ss values for AOM 400 and AL $882 \mathrm{mg}$ administered every 4 weeks were comparable, while AL $441 \mathrm{mg}$ resulted in considerably lower Cavg,ss values. $\mathrm{Cmin}, \mathrm{ss}$ values for the intragluteal injection of AOM 400 and the intragluteal injection of AL $882 \mathrm{mg}$ every 4 weeks were also found to be similar $(200 \mathrm{ng} / \mathrm{mL}$ and $175 \mathrm{ng} / \mathrm{mL}$, respectively) [99]. Table 1 summarizes the comparative studies discussed here.

Table 1. Comparative studies.

\begin{tabular}{|c|c|c|c|}
\hline Author (Year) & Groups Studied and Intervention & Results and Findings & Conclusions \\
\hline $\begin{array}{l}\text { Cameron C. et al. } \\
\text { (2017) [98] }\end{array}$ & $\begin{array}{l}\text { A NMA, with searches from MED- LINE } \\
\text { Embase, Cochrane CENTRAL, PsycINFC } \\
\text { ClinicalTrials.gov, International Clinical } \\
\text { Trials Registry Platform, and gray } \\
\text { literature which identified four Phase III } \\
\text { clinical trials ( } 1 \text { of AL and } 3 \text { of PP), for } \\
\text { indirect comparison of AL and PP. } \\
\text { Active-treatment groups were AL ( } 441 \mathrm{~m} \\
\text { and } 882 \mathrm{mg} \text { monthly) and PP (156 mg an } \\
234 \mathrm{mg} \text { monthly). }\end{array}$ & $\begin{array}{l}\text { All four groups versus placebo } \\
\text { resulted in substantial reduction } \\
\text { in acute symptoms, as measured } \\
\text { by the positive and negative } \\
\text { syndrome scale; the range of } \\
\text { mean difference was }-8.12 \text { to } \\
-12.01, \text { with overlapping } 95 \% \\
\text { credible intervals. No differences } \\
\text { in efficacy, safety or tolerability } \\
\text { were found between } \\
\text { active-treatment groups. }\end{array}$ & $\begin{array}{c}\mathrm{AL} \text { and PP are equally } \\
\text { efficacious in treating adults } \\
\text { with acute exacerbation of } \\
\text { schizophrenia. }\end{array}$ \\
\hline $\begin{array}{l}\text { Salzman P. et al. } \\
\text { (2017) [99] }\end{array}$ & $\begin{array}{c}\text { Aripiprazole steady-state plasma } \\
\text { concentrations for two different LAI } \\
\text { formulations, (aripiprazole once-monthly } \\
400 \mathrm{mg} \text { [AOM 400] and AL), were } \\
\text { compared. } \mathrm{C}_{\mathrm{avg}, \mathrm{ss}} \text { for AOM } 400 \text { were } \\
\text { obtained from a population Pk model, } \\
\text { while those for AL were obtained from th } \\
\text { Center for Drug Evaluation and Research } \\
\text { (CDER). } \text { Cmin,ss for both LAIs were } \text { obtained from previously published } \\
\text { clinical trials. }\end{array}$ & $\begin{array}{c}\mathrm{C}_{\text {avg,ss }} \text { values for AOM } 400 \text { and } \\
\text { AL } 882 \mathrm{mg} \text { given every } 4 \text { weeks } \\
\text { were comparable, while AL } 441 \\
\text { mg resulted in considerably lower } \\
\mathrm{C}_{\text {avg,ss }} \text { values. } \mathrm{C}_{\text {min,ss }} \text { values for } \\
\text { the intragluteal injection of AOM } \\
400 \text { and the intragluteal injection } \\
\text { of AL } 882 \mathrm{mg} \text { every } 4 \text { weeks were } \\
\text { also similar }(200 \mathrm{ng} / \mathrm{mL} \text { and } 175 \\
\mathrm{ng} / \mathrm{mL} \text {, respectively). }\end{array}$ & $\begin{array}{l}\text { Both AOM } 400 \text { mg and AL } \\
882 \text { mg administered every } 4 \\
\text { weeks provided similar } \\
\text { Aripiprazole steady-state } \\
\text { plasma concentrations. }\end{array}$ \\
\hline Author (Year) & $\begin{array}{l}\text { Groups Studied and } \\
\text { Intervention }\end{array}$ & Results and Findings & Conclusions \\
\hline $\begin{array}{l}\text { Turncliff R. et al. } \\
\text { (2014) [85] }\end{array}$ & $\begin{array}{l}\text { A phase } 1 \text {, randomized, } \\
\text { open-label, single-dose study. } 46 \\
\text { patients were randomized to two } \\
\text { groups; } 441 \text { mg IM injection } \\
\text { administered at deltoid site or } 441 \\
\text { mg IM injection at gluteal site. } \\
\text { Maximum plasma concentration } \\
\text { ( } \mathrm{C}_{\text {max }} \text { ) and area under the plasma } \\
\text { concentration time curve from } \\
\text { time zero to infinity (AUC } \mathrm{C}_{0-\text { inf }} \text { ) of } \\
\text { aripiprazole and its metabolite } \\
\text { dehydro-aripiprazole were } \\
\text { measured. AEs were measured as } \\
\text { tolerability outcomes }\end{array}$ & $\begin{array}{l}\text { Deltoid administration resulted in } \\
\text { higher } \mathrm{C}_{\max } \text { aripiprazole } \\
\text { concentration, while } \mathrm{AUC}_{0 \text {-inf }} \\
\text { was similar for both sites. } \\
\text { Dehydro-aripiprazole exposure } \\
\text { was } 33 \% \text { and } 36 \% \text { of aripiprazole } \\
\text { exposure for deltoid and gluteal } \\
\text { administration, respectively. The } \\
\text { most common AE was injection } \\
\text { site pain, with a higher incidence } \\
\text { in the deltoid group. }\end{array}$ & $\begin{array}{l}\text { Deltoid and gluteal injection sites } \\
\text { provided similar levels of } \\
\text { exposure and were both } \\
\text { well-tolerated in patients with } \\
\text { chronic stable schizophrenia. }\end{array}$ \\
\hline
\end{tabular}


Table 2. Cont.

\begin{tabular}{|c|c|c|c|}
\hline Author (Year) & $\begin{array}{l}\text { Groups Studied and } \\
\text { Intervention }\end{array}$ & Results and Findings & Conclusions \\
\hline $\begin{array}{l}\text { Meltzer H. et al. } \\
\quad \text { (2015) [87] }\end{array}$ & $\begin{array}{c}\text { A phase 3, randomized, } \\
\text { double-blind, placebo-controlled } \\
\text { trial. } 623 \text { patients (ages 18-70) } \\
\text { experiencing an acute } \\
\text { exacerbation of schizophrenia } \\
\text { were randomized 2:2:1:1 to AL } 441 \\
\text { mg, AL } 882 \mathrm{mg} \text {, placebo low } \\
\text { volume, and placebo high volume, } \\
\text { respectively. Injections were } \\
\text { administered in the gluteal } \\
\text { muscle on days 1, } 29 \text { and } 57 \text {. The } \\
\text { primary efficacy endpoint was } \\
\text { change from baseline to day } 85 \text { in } \\
\text { PANSS total score, and the } \\
\text { secondary efficacy endpoint was } \\
\text { CGI-I score at day } 85 .\end{array}$ & $\begin{array}{l}\text { Placebo-adjusted least squares } \\
\text { mean differences of PANSS total } \\
\text { score were significantly lower for } \\
\text { both AL } 441 \mathrm{mg} \text { and AL } 882 \mathrm{mg} ; p \\
<0.001 \text { for both. CGI-I scores for } \\
\text { both AL groups were also } \\
\text { significantly better than placebo } \\
\text { (Wilcoxon rank sum test: } p< \\
0.001 \text { ). }\end{array}$ & $\begin{array}{l}\text { Both doses of AL were highly } \\
\text { efficacious in treating an acute } \\
\text { exacerbation of schizophrenia, } \\
\text { with a safety and tolerability } \\
\text { profile similar to oral aripiprazole, } \\
\text { therefore representing a new } \\
\text { treatment option. }\end{array}$ \\
\hline $\begin{array}{l}\text { Nasrallah H. et al. } \\
\text { (2016) [94] }\end{array}$ & $\begin{array}{l}\text { Patients with schizophrenia were } \\
\text { randomly assigned to AL } 441 \mathrm{mg} \text {, } \\
\text { AL } 882 \mathrm{mg} \text {, or placebo } \\
\text { intramuscularly. Body weight, } \\
\text { body mass index, fasting blood } \\
\text { glucose and serum lipids, } \\
\text { glycosylated hemoglobin } \\
\text { (HbA1c), and prolactin were the } \\
\text { parameters evaluated for } 12 \\
\text { weeks. Treatment-emergent } \\
\text { adverse events (AEs) were used } \\
\text { for safety evaluations. }\end{array}$ & $\begin{array}{l}\text { For both AL groups compared } \\
\text { with placebo, mean body weight } \\
\text { increased slightly and prolactin } \\
\text { levels decreased, while changes in } \\
\text { lipid parameters (total cholesterol, } \\
\text { LDL cholesterol and triglycerides), } \\
\text { plasma glucose, and HbA1c were } \\
\text { insignificant. The incidence of } \\
\text { AEs related to metabolic } \\
\text { parameters was low. }\end{array}$ & $\begin{array}{l}\text { Both AL } 441 \mathrm{mg} \text { and AL } 882 \mathrm{mg} \\
\text { showed a small weight gain } \\
\text { compared with placebo but } \\
\text { otherwise reflected a low-risk } \\
\text { metabolic profile. }\end{array}$ \\
\hline $\begin{array}{l}\text { Citrome L. et al. } \\
\text { (2016) [95] }\end{array}$ & $\begin{array}{l}\text { Patients with schizophrenia were } \\
\text { randomly assigned to AL } 441 \mathrm{mg} \text {, } \\
\text { AL } 882 \mathrm{mg} \text {, or placebo } \\
\text { intramuscularly. Study endpoints } \\
\text { were PANSS Hostility item (P7) } \\
\text { score in the subpopulation of } \\
\text { patients with a PANSS Hostility } \\
\text { item P7 score of more than } 1 \text { at } \\
\text { baseline, PSP disturbing and } \\
\text { aggressive behavior domain and } \\
\text { PANSS excited component } \\
\text { (PANSS-EC) score. }\end{array}$ & $\begin{array}{l}\text { AL groups compared with } \\
\text { placebo resulted in significant } \\
\text { lowering in proportion with } \\
\text { PANSS Hostility item P7 more } \\
\text { than } 1 \text { at endpoint }(p<0.05) \text {, as } \\
\text { well as significant improvement ( } p \\
<0.05) \text { in PANSS excited } \\
\text { component score. The proportion } \\
\text { of patients with aggressive } \\
\text { behavior on the Personal and } \\
\text { Social Performance scale was also } \\
\text { significantly lower for both } 441 \\
\text { mg and } 882 \text { mg compared with } \\
\text { placebo ( } p=0.006 \text { and } p<0.001, \\
\text { respectively). }\end{array}$ & $\begin{array}{l}\text { AL treatment displayed efficacy } \\
\text { in reducing agitation and hostility } \\
\text { in patients with schizophrenia. }\end{array}$ \\
\hline $\begin{array}{l}\text { Nasrallah H. et al. } \\
\text { (2017) [88] }\end{array}$ & $\begin{array}{c}\text { Phase } 3 \text {, international, 52-week, } \\
\text { open-label extension study with } \\
478 \text { patients. } 368 \text { received AL } 882 \\
\text { mg and } 110 \text { received AL } 441 \mathrm{mg} \\
\text { as their fixed-dose regimen. Of } \\
\text { the } 478,236 \text { entered from a phase } \\
3 \text { study and } 242 \text { entered as } \\
\text { outpatients with no prior AL } \\
\text { exposure and a Clinical Global } \\
\text { Impression-Severity score of } \leq 3 \\
\text { [mild] at screening. Metabolic } \\
\text { parameters of weight, fasting } \\
\text { blood sugar, lipids and serum } \\
\text { prolactin were assessed for } \\
\text { changes }\end{array}$ & $\begin{array}{l}\text { The mean changes from baseline } \\
\text { in the overall population were } \\
+1.1 \mathrm{mg} / \mathrm{dL} \text { for glucose, }+0.07 \text { for } \\
\text { glycated hemoglobin }(\mathrm{Hb} \text { Alc), } \\
-3.3 \mathrm{mg} / \mathrm{dL} \text { for total cholesterol, } \\
\text { and }-5.3 \mathrm{mg} / \mathrm{dL} \text { for triglycerides, } \\
\text { while prolactin change from } \\
\text { baseline was }-8.7 \mathrm{ng} / \mathrm{mL}(14.7) \\
\text { for men and }-14.9(43.4) \mathrm{ng} / \mathrm{mL} \\
\text { for women. The retention rates at } \\
6 \text { months and } 1 \text { year were } 86 \% \\
\text { and } 68 \% \text {, respectively. }\end{array}$ & $\begin{array}{l}\text { Long-term AL treatment lead to } \\
\text { slight lowering of serum with } \\
\text { insubstantial changes in other } \\
\text { assessed parameters. }\end{array}$ \\
\hline
\end{tabular}


Table 2. Cont.

\begin{tabular}{|c|c|c|c|}
\hline Author (Year) & $\begin{array}{l}\text { Groups Studied and } \\
\text { Intervention }\end{array}$ & Results and Findings & Conclusions \\
\hline $\begin{array}{l}\text { Potkin S. et al. } \\
\text { (2017) [90] }\end{array}$ & $\begin{array}{l}\text { Patients with schizophrenia were } \\
\text { randomly assigned to AL } 441 \mathrm{mg} \text {, } \\
\text { AL } 882 \mathrm{mg} \text {, or placebo } \\
\text { intramuscularly. Post-hoc analysis } \\
\text { of the patient subgroup with } \\
\text { severe psychotic symptoms } \\
\text { (PANSS total score greater than } \\
\text { the median score of } 92 \text { ). Primary } \\
\text { outcome measured was mean } \\
\text { change from baseline to day } 85 \mathrm{in} \\
\text { PANSS Total score. Categorical } \\
\text { responder rate (defined as } \geq 30 \% \\
\text { improvement in PANSS Total } \\
\text { score or a final CGI-I score of } \leq 2 \\
\text { [very much or much improved]) } \\
\text { was also evaluated. }\end{array}$ & $\begin{array}{l}\text { Both AL } 441 \mathrm{mg} \text { and } 882 \mathrm{mg} \\
\text { demonstrated statistically } \\
\text { significant and clinically } \\
\text { meaningful improvements in } \\
\text { PANSS Total score, with } \\
\text { placebo-adjusted differences of } \\
-14.7(p<0.0001) \text { and }-16.6(p< \\
0.0001), \text { respectively, as well as } \\
\text { significant findings with } \\
\text { responder rates }(p<0.001) \text { for } \\
\text { both groups vs. placebo. } \\
\text { Moreover, AL- } 882 \text { mg resulted in } \\
\text { a higher responder rate. }\end{array}$ & $\begin{array}{l}\text { Both doses of AL demonstrated } \\
\text { robust efficacy in treating patients } \\
\text { with severe psychotic symptoms. } \\
\text { The } 882 \mathrm{mg} \text { dose displayed a } \\
\text { numerically greater improvement } \\
\text { in symptoms and proportion of } \\
\text { responders. }\end{array}$ \\
\hline $\begin{array}{l}\text { Targum S. et al. } \\
\text { (2017) [91] }\end{array}$ & $\begin{array}{l}\text { Patients with schizophrenia were } \\
\text { randomly assigned AL } 441 \mathrm{mg} \text {, } \\
\text { AL } 882 \mathrm{mg} \text {, or placebo } \\
\text { intramuscularly. Post-hoc gender } \\
\text { and age analysis of AL treatment } \\
\text { response, with age groups }<30, \\
30-39,40-49 \text {, and } 50-69 \text { years old. } \\
\text { The primary outcome measured } \\
\text { was change in total PANSS score } \\
\text { from baseline to day } 85 \text {. } \\
\text { Categorical treatment response } \\
\text { (defined as } \geq 30 \% \text { total PANSS } \\
\text { score improvement from baseline) } \\
\text { was also measured. }\end{array}$ & $\begin{array}{l}\text { ANCOVA analysis of change in } \\
\text { PANSS score showed no } \\
\text { significant interaction effects } \\
\text { between age and treatment for } \\
\text { both AL } 441 \mathrm{mg} \text { versus placebo } \\
\text { and AL } 882 \mathrm{mg} \text { versus placebo; (F } \\
=0.27 ; p=0.60 \text { ) and (F = 0.92; } p= \\
0.34) \text {, respectively. The odds ratios } \\
\text { (ORs) for treatment response rates } \\
\text { showed higher association for } \\
\text { either AL dose versus placebo for } \\
\text { all age groups. } \\
\text { No interaction effect between } \\
\text { gender and treatment was } \\
\text { observed, with outcomes for both } \\
\text { men and women being better in } \\
\text { AL groups than placebo. }\end{array}$ & $\begin{array}{l}\text { AL } 441 \mathrm{mg} \text { and AL } 882 \mathrm{mg} \text { led to } \\
\text { significant improvement in mean } \\
\text { total PANSS score and categorical } \\
\text { treatment response compared } \\
\text { with placebo, regardless of patient } \\
\text { age and gender. }\end{array}$ \\
\hline $\begin{array}{l}\text { McEvoy J. et al. } \\
\text { (2017) [96] }\end{array}$ & $\begin{array}{l}\text { Post-hoc analysis of long-term } \\
\text { outcomes in patients who had } \\
\text { completed both a phase } 3 \text { and } \\
\text { extension study. Outcomes } \\
\text { measured were rates of retention } \\
\text { and remission, as well as } \\
\text { treatment response trajectories, as } \\
\text { measured by PANSS total and } \\
\text { CGI-S item scores in AL } 441 \mathrm{mg} \\
\text { and AL } 882 \text { mg groups. }\end{array}$ & $\begin{array}{l}\text { A statistically significant decrease } \\
\text { occurred for PANSS total score }(p \\
<0.0001 \text { for both groups) and } \\
\text { CGI-S scores ( }(p<0.0001 \text { for both } \\
\text { groups). By week } 64, \text { remission } \\
\text { rates were } 73.8 \% \text { and } 68.1 \% \text { in the } \\
441 \mathrm{mg} \text { and } 882 \mathrm{mg} \text { groups, } \\
\text { respectively, with the median } \\
\text { remission time from the } \\
\text { beginning of the } 12 \text { weeks being } \\
16.1 \text { and } 16.4 \text { weeks, respectively. } \\
\text { Retention rates were } 72.8 \% \text { and } \\
66.0 \% \text { for the } 441 \text { mg and } 882 \mathrm{mg} \\
\text { groups, respectively. }\end{array}$ & $\begin{array}{l}\text { Both Al } 441 \mathrm{mg} \text { and AL } 882 \mathrm{mg} \\
\text { exhibited continued therapeutic } \\
\text { benefit in the long-term, as } \\
\text { evidenced by high retention rates } \\
\text { and significant improvements in } \\
\text { clinical symptoms. }\end{array}$ \\
\hline $\begin{array}{l}\text { Miller B. et al. } \\
\text { (2019) [89] }\end{array}$ & $\begin{array}{l}\text { A phase 4, 6-month, prospective, } \\
\text { open-label study in which } 51 \\
\text { patients switched from either PP } \\
\text { or RLAI to AL. Outcomes } \\
\text { measured were CGI-S scores, } \\
\text { BPRS scores, all-cause and } \\
\text { medication-related } \\
\text { discontinuation and adverse } \\
\text { events. AEs were also assessed. }\end{array}$ & $\begin{array}{l}\text { CGI-S and BPRS scores showed } \\
\text { significant improvement, and the } \\
\text { retention rate with all-cause and } \\
\text { medication-related } \\
\text { discontinuation rates at the end of } \\
6 \text { months was } 30 \% \text { and } 9 \% \text {, } \\
\text { respectively. The retention rate at } \\
\text { the end of } 6 \text { months was } 68.6 \% \text {, } \\
\text { while the incidence of AEs was } \\
41.2 \% \text {, with the most frequent } \\
\text { psychotic disorder, anxiety and } \\
\text { schizophrenia. }\end{array}$ & $\begin{array}{l}\text { Patients being treated with PP or } \\
\text { RLAI who experience continued } \\
\text { symptoms or tolerability issues } \\
\text { can switch to AL, as the latter is } \\
\text { well-tolerated. }\end{array}$ \\
\hline
\end{tabular}


Table 2. Cont.

\begin{tabular}{|c|c|c|c|}
\hline Author (Year) & $\begin{array}{l}\text { Groups Studied and } \\
\text { Intervention }\end{array}$ & Results and Findings & Conclusions \\
\hline $\begin{array}{l}\text { Correll C. et al. } \\
\text { (2019) [92] }\end{array}$ & $\begin{array}{l}\text { Patients with schizophrenia were } \\
\text { randomly assigned to AL } 441 \mathrm{mg} \text {, } \\
\text { AL } 882 \mathrm{mg} \text {, or placebo } \\
\text { intramuscularly. Post-hoc social } \\
\text { and functional outcomes analysis } \\
\text { of } 596 \text { of the total } 623 \text { patients. } \\
\text { Outcomes measured were } 6 \text {-item } \\
\text { PANSS Prosocial subscale, } 4 \text {-item } \\
\text { PANSS Prosocial subscale and } \\
\text { Personal and Social Performance } \\
\text { (PSP) total score. }\end{array}$ & $\begin{array}{l}\text { Both 6- and 4-item PANSS } \\
\text { Prosocial Scores showed } \\
\text { significant improvement for both } \\
\text { doses of AL versus placebo, with } \\
\text { the treatment effect sizes for } \\
\text { PANSS Prosocial scores with AL } \\
441 \mathrm{mg} \text { versus placebo being } \\
\text { Cohen's d=0.52 and AL } 882 \mathrm{mg} \\
\text { versus placebo being Cohen's } \\
\text { d=0.49. There was a significant } \\
\text { increase in PSP total score for both } \\
\text { doses versus placebo, with } \\
\text { treatment effect sizes of Cohen's d } \\
=0.51 \text { and } 0.59 \text { for AL } 441-\mathrm{mg} \text { or } \\
\text { AL } 882 \text {-mg compared with } \\
\text { placebo, respectively. }\end{array}$ & $\begin{array}{l}\text { Treatment with AL } 441 \text { mg and } \\
\text { AL } 882 \text { mg compared with } \\
\text { placebo produces significant } \\
\text { improvements in social } \\
\text { functioning. }\end{array}$ \\
\hline $\begin{array}{l}\text { Citrome L. et al. } \\
\text { (2019) [93] }\end{array}$ & $\begin{array}{l}\text { Patients with schizophrenia were } \\
\text { randomly assigned to AL } 441 \mathrm{mg} \text {, } \\
\text { AL } 882 \mathrm{mg} \text {, or placebo } \\
\text { intramuscularly. Post-hoc analysis } \\
\text { with categorical efficacy and } \\
\text { tolerability. Outcomes measured } \\
\text { were number needed to treat } \\
\text { (NNT) for therapeutic outcomes, } \\
\text { number needed to harm (NNH) } \\
\text { for adverse outcomes, and } \\
\text { likelihood to be helped or harmed } \\
\text { (LHH). }\end{array}$ & $\begin{array}{c}\text { For pooled doses of AL, an NNT } \\
\text { of } 6 \text { ( } 95 \% \text { CI: } 5-11 \text { ) was calculated } \\
\text { when the response threshold was } \\
\geq 30 \% \text { improvement from baseline } \\
\text { PANSS total score. } \\
\text { For discontinuation due to AEs, a } \\
\text { NNH estimate of }-8 \text { ( } 95 \% \text { CI: }-6 \\
\text { to }-15) \text { for the pooled doses of } \\
\text { AL vs placebo was calculated, } \\
\text { while for Akathisia, the NNH was } \\
14 \text { (95\% CI: } 9-33) \text {. LHH value, } \\
\text { using the NNT for response } \\
\text { ( } \geq 30 \% \text { reduction from baseline in } \\
\text { PANSS total score) and the NNH } \\
\text { for akathisia, was } 2.3 \text {. }\end{array}$ & $\begin{array}{l}\text { Aripiprazole lauroxil is efficacious } \\
\text { and well-tolerated in the } \\
\text { treatment of an acute exacerbation } \\
\text { of schizophrenia, as evidenced by } \\
\text { NNT and NNH values. }\end{array}$ \\
\hline $\begin{array}{l}\text { Peters L. et al. } \\
\text { (2019) [97] }\end{array}$ & $\begin{array}{l}\text { A systematic review of } 31 \text { RCTs ( } 7 \\
\text { primary studies and } 24 \text { post hoc } \\
\text { analyses) to evaluate comparisons } \\
\text { of LAIs to placebo, OAPs or } \\
\text { another LAI and } 5 \text { meta-analyses } \\
\text { of RCTs comparing LAI to OAPs, } \\
\text { all published 2016-2019. AL was } \\
\text { among the LAIs analyzed. }\end{array}$ & $\begin{array}{l}\text { LAIs were vastly superior to } \\
\text { placebo and partly superior to } \\
\text { OAPs for prevention of relapse } \\
\text { and hospitalization and were } \\
\text { comparable to OAPs for all-cause } \\
\text { discontinuation, functioning, } \\
\text { quality of life, and tolerability, as } \\
\text { well as being associated with } \\
\text { higher patient satisfaction and } \\
\text { service engagement. Results from } \\
\text { recent meta-analyses did not show } \\
\text { an advantage for OAPs over LAIs. }\end{array}$ & $\begin{array}{c}\text { Results from RCTs show that LAIs } \\
\text { outperform placebo but are better } \\
\text { than OAPs in only some aspects. } \\
\text { Meta-analyses results do not } \\
\text { reveal an advantage for OAP vs. } \\
\text { placebo. }\end{array}$ \\
\hline $\begin{array}{l}\text { Weiden P. et al. } \\
\text { (2020) [86] }\end{array}$ & $\begin{array}{l}\text { A phase I, open-label, multicenter } \\
\text { study, with } 105 \text { patients } \\
\text { randomized to one of three AL } \\
\text { dose regimens of } 1064 \text {-mg } \\
\text { injections every } 8 \text { weeks, } 882-\mathrm{mg} \\
\text { injections every } 6 \text { weeks, or } \\
\text { 441-mg injections every } 4 \text { weeks, } \\
\text { for a total of } 24 \text { weeks, with a } \\
\text { 20-week follow-up. Plasma } \\
\text { aripiprazole concentrations and } \\
\text { AEs were evaluated. }\end{array}$ & $\begin{array}{l}\text { Both 1064-mg and 882-mg } \\
\text { regimens provided comparable } \\
\text { aripiprazole exposure, higher } \\
\text { than that of } 441-\mathrm{mg} \text {. Most AEs } \\
\text { were mild or moderate, with } \\
\text { injection-site pain being the most } \\
\text { frequent AE in all three regimens. } \\
\text { Discontinuation due to TEAEs } \\
\text { was } 2.9 \%, 11.8 \% \text { and } 5.7 \% \text { in the } \\
\text { 1064-mg, } 882-\mathrm{mg} \text { and } 441-\mathrm{mg} \\
\text { groups, respectively. }\end{array}$ & $\begin{array}{c}\text { All three dosing regimens provide } \\
\text { continuous exposure to AL, } \\
\text { including 1064-mg administered } \\
\text { every } 2 \text { months, and all produced } \\
\text { a safety profile similar to } \\
\text { previously established safety } \\
\text { profiles. }\end{array}$ \\
\hline
\end{tabular}

\section{Conclusions}

Schizophrenia consists of positive symptoms, negative symptoms, and cognitive dysfunction. Several theories regarding pathogenesis have been proposed, including the neurodevelopmental theory and dopaminergic imbalance. There are several risk factors that contribute to the development of schizophrenia, including genetic factors, history of cannabis use, and childhood trauma. The pharmacological treatment of schizophrenia is largely based on mitigating dopaminergic imbalance. 
First-generation antipsychotics work by non-selectively blocking $\mathrm{D}_{2}$ receptors in the CNS. While effective at mitigating positive symptoms, FGAs lead to unwanted extrapyramidal symptoms and elevated prolactin levels due to non-selectivity. FGAs have not been shown to reduce negative symptoms or improve cognitive impairment. Second generation antipsychotics also work by blocking dopaminergic receptors. SGAs have been shown to produce less extrapyramidal symptoms and can treat both positive and negative symptoms; however, SGAs show no improvement in cognitive dysfunction. Third generation antipsychotics, including aripiprazole, can be characterized as $\mathrm{D}_{2}$ partial agonists or $\mathrm{D}_{2}$-biased ligands.

Aripiprazole can act as an antagonist in areas with high dopamine levels and an agonist in areas with low dopamine levels, thus giving it the name "dopamine stabilizer." The use of aripiprazole has also been shown to minimize extrapyramidal symptoms when compared with first- and second-generation antipsychotics. Aripiprazole lauroxil is a prodrug of aripiprazole and is given as an IM injection, which helps improve treatment rates in patients who are not compliant in taking once-daily oral medication. AL is metabolized by CYP3A4 and CYP2D6 in the liver. The use of AL is contraindicated in patients with known aripiprazole hypersensitivity and in dementia-related psychosis. Side effects are known to include weight gain, akathisia, neuroleptic malignant syndrome, tardive dyski-

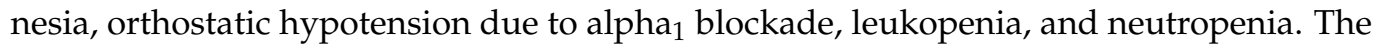
use of AL has shown significant statistical and clinical efficacy in treating the symptoms of schizophrenia.

Author Contributions: K.M., H.G., J.H. and F.I. were responsible for the writing. A.N.E., A.M.K., A.D.K., O.V., J.P.II, I.U. and E.M.C. were all editors. All authors have read and agreed to the published version of the manuscript.

Funding: This research received no external funding.

Institutional Review Board Statement: Ethical review and approval were waived for this study, due to this being a review with no human participants.

Informed Consent Statement: Not applicable.

Data Availability Statement: No data was collected in this manuscript but all were cited as appropriate and can be found in the reference section.

Conflicts of Interest: Authors declare no conflict of interest.

\section{References}

1. Kahn, R.S.; Sommer, I.E.; Murray, R.M.; Meyer-Lindenberg, A.; Weinberger, D.R.; Cannon, T.D.; O’Donovan, M.; Correll, C.U.; Kane, J.M.; van Os, J.; et al. Schizophrenia. Nat. Rev. Dis. Prim. 2015, 12, 1. Available online: https:/ / pubmed.ncbi.nlm.nih.gov/ 27189524/ (accessed on 20 June 2021).

2. Bora, E.; Yücel, M.; Pantelis, C. Cognitive impairment in schizophrenia and affective psychoses: Implications for dsm-v criteria and beyond. Schizophr. Bull. 2010, 36, 36-42. Available online: https://pubmed.ncbi.nlm.nih.gov/19776206/ (accessed on 20 June 2021).

3. Kahn, R.S.; Keefe, R.S.E. Schizophrenia is a cognitive illness: Time for a change in focus. JAMA Psychiatry Am. Med. Assoc. 2013, 7, 1107-1112. Available online: https:/ / pubmed.ncbi.nlm.nih.gov/23925787/ (accessed on 22 June 2021).

4. Harvey, P.D. Assessing disability in schizophrenia: Tools and contributors. J. Clin. Psychiatry 2014, 75, e27. Available online: https: / pubmed.ncbi.nlm.nih.gov / 25373132/ (accessed on 22 June 2021).

5. Reichenberg, A.; Feo, C.; Prestia, D.; Bowie, C.R.; Patterson, T.L.; Harvey, P.D. The course and correlates of everyday functioning in schizophrenia. Schizophr. Res. Cogn. 2014, 1, e47-e52. Available online: https://pubmed.ncbi.nlm.nih.gov/25045625/ (accessed on 23 June 2021).

6. American Psychiatric Publishing. DSM-5®Handbook of Differential Diagnosis. DSM-5®Handbook of Differential Diagnosis; American Psychiatric Publishing: Washington, DC, USA, 2013.

7. Fenton, W.S. Depression, suicide, and suicide prevention in schizophrenia. Suicide Life Threat. Behav. 2000, 30, 34-49. Available online: http:/ / www.ncbi.nlm.nih.gov/pubmed/10782717 (accessed on 23 June 2021).

8. Siris, S.G. Depression in schizophrenia: Perspective in the era of "atypical" antipsychotic agents. Am. J. Psychiatry 2000, 157, 1379-1389. Available online: https:/ / pubmed.ncbi.nlm.nih.gov/10964850/ (accessed on 23 June 2021). 
9. Regier, D.A.; Farmer, M.E.; Rae, D.S.; Locke, B.Z.; Keith, S.J.; Judd, L.L.; Goodwin, F.K. Comorbidity of Mental Disorders With Alcohol and Other Drug Abuse: Results From the Epidemiologic Catchment Area (ECA) Study. JAMA J. Am. Med. Assoc. 1990, 264, 2511-2518. Available online: https:/ /jamanetwork.com/journals/jama/fullarticle/383975 (accessed on 23 June 2021). [CrossRef]

10. AHRQ. Treatments for Schizophrenia in Adults: A Systematic Review e. Available online: www.ahrq.gov (accessed on 23 June 2021).

11. McGrath, J.; Saha, S.; Chant, D.; Welham, J. Schizophrenia: A concise overview of incidence, prevalence, and mortality. Epidemiologic Reviews. Epidemiol. Rev. 2008, 30,67-76. Available online: https://pubmed.ncbi.nlm.nih.gov/18480098/ (accessed on 23 June 2021).

12. Tsuang, M. Schizophrenia: Genes and environment. Biol. Psychiatry 2000, 47, 210-220. Available online: https://pubmed.ncbi. nlm.nih.gov/10682218/ (accessed on 25 June 2021).

13. Heston, L.L. Psychiatric disorders in foster home reared children of schizophrenic mothers. Br. J. Psychiatry 1966, 112, 819-825. Available online: https:/ / pubmed.ncbi.nlm.nih.gov/5966555/ (accessed on 25 June 2021).

14. Jirtle, R.L.; Skinner, M.K. Environmental epigenomics and disease susceptibility. Nat. Rev. Genet. 2007, 8, 253-262. Available online: https: / / pubmed.ncbi.nlm.nih.gov/17363974/ (accessed on 25 June 2021). [CrossRef]

15. Selvaraj, S.; Arnone, D.; Cappai, A.; Howes, O. Alterations in the serotonin system in schizophrenia: A systematic review and meta-analysis of postmortem and molecular imaging studies. Neurosci. Biobehav. Rev. 2014, 45, 233-245. Available online: https: / / pubmed.ncbi.nlm.nih.gov/24971825/ (accessed on 25 June 2021). [CrossRef] [PubMed]

16. Celada, P.; Victoria Puig, M.; Artigas, F. Serotonin modulation of cortical neurons and networks. Front. Integr. Neurosci. 2013, 7, 25. Available online: https:/ / pubmed.ncbi.nlm.nih.gov/23626526/ (accessed on 25 June 2021). [CrossRef] [PubMed]

17. The Cortical Serotonin2a Receptor and The Pathology of Schizophrenia: A Likely Accomplice-Pubmed. Available online: https:/ / pubmed.ncbi.nlm.nih.gov/12641722/ (accessed on 25 June 2021).

18. Dean, B.; Pavey, G.; Thomas, D.; Scarr, E. Cortical serotonin7, 1D and 1F receptors: Effects of schizophrenia, suicide and antipsychotic drug treatment. Schizophr. Res. 2006, 88, 265-274. Available online: https://pubmed.ncbi.nlm.nih.gov/16916599/ (accessed on 25 June 2021). [CrossRef] [PubMed]

19. McGorry, P.D.; Purcell, R.; Hickie, I.B.; Yung, A.R.; Pantelis, C.; Jackson, H.J. Clinical staging: A heuristic model for psychiatry and youth mental health. Med. J. 2007, 187, S40-S42. Available online: https://onlinelibrary.wiley.com/doi/abs/10.5694/j.1326-5 377.2007.tb01335.x (accessed on 27 June 2021). [CrossRef] [PubMed]

20. Dean, B.; Copolov, D.; Scarr, E. Understanding the pathophysiology of schizophrenia: Contributions from the Melbourne Psychiatric Brain Bank. Schizophr. Res. 2016, 177, 108-114. Available online: https://pubmed.ncbi.nlm.nih.gov/27184458/ (accessed on 27 June 2021). [CrossRef]

21. Perry, E.; Walker, M.; Grace, J.; Perry, R. Acetylcholine in mind: A neurotransmitter correlate of consciousness? Trends in Neurosciences. Trends Neurosci. 1999, 22, 273-280. Available online: https:/ / pubmed.ncbi.nlm.nih.gov/10354606/ (accessed on 27 June 2021). [CrossRef]

22. Thiele, A. Muscarinic signaling in the brain. Annual Review of Neuroscience. Annu. Rev. Neurosci. 2013, 36, 271-294. Available online: https:/ / pubmed.ncbi.nlm.nih.gov/23841840/ (accessed on 27 June 2021). [CrossRef]

23. Dean, B.; McLeod, M.; Keriakous, D.; McKenzie, J.; Scarr, E. Decreased muscarinic1 receptors in the dorsolateral prefrontal cortex of subjects with schizophrenia. Mol. Psychiatry 2002, 7, 1083-1091. Available online: https:/ / pubmed.ncbi.nlm.nih.gov/12476323/ (accessed on 27 June 2021). [CrossRef]

24. Mancama, D.; Arranz, M.J.; Landau, S.; Kerwin, R. Reduced expression of the muscarinic 1 receptor cortical subtype in schizophrenia. Am. J. Med. Genet. 2003, 119, 2-6. Available online: https://pubmed.ncbi.nlm.nih.gov/12707929/ (accessed on 27 June 2021). [CrossRef]

25. Mirnics, K.; Pevsner, J. Progress in the use of microarray technology to study the neurobiology of disease. Nat. Neurosci. 2004, 7 , 434-439. Available online: https:/ / pubmed.ncbi.nlm.nih.gov/15114354/ (accessed on 27 June 2021). [CrossRef]

26. Dean, B.; Keriakous, D.; Thomas, E.; Scarr, E. Understanding the Pathology of Schizophrenia: The Impact of High- Throughput Screening of the Genome and Proteome in Postmortem CNS. Curr. Psychiatry Rev. 2005, 1, 1-9. [CrossRef]

27. Davis, J.; Eyre, H.; Jacka, F.N.; Dodd, S.; Dean, O.; McEwen, S.; Debnath, M.; McGrath, J.; Maes, M.; Amminger, P.; et al. A review of vulnerability and risks for schizophrenia: Beyond the two hit hypothesis. Neurosci. Biobehav. Rev. 2016, 65, 185-194. Available online: https:/ / pubmed.ncbi.nlm.nih.gov /27073049/ (accessed on 27 June 2021). [CrossRef]

28. Weinberger, D.R. Implications of Normal Brain Development for the Pathogenesis of Schizophrenia. Arch. Gen. Psychiatry. 1987, 44, 660-669. Available online: https:/ / pubmed.ncbi.nlm.nih.gov/3606332/ (accessed on 28 June 2021). [CrossRef]

29. Murray, R.M.; Lewis, S.W.; Lecturer, L. Is schizophrenia a neurodevelopmental disorder? Br. Med. J. 1987, 295, 681-682. Available online: https:/ / pubmed.ncbi.nlm.nih.gov/3117295/ (accessed on 28 June 2021). [CrossRef] [PubMed]

30. Glausier, J.R.; Lewis, D.A. Dendritic spine pathology in schizophrenia. Neuroscience 2013, 251, 90-107. Available online: https:/ / pubmed.ncbi.nlm.nih.gov / 22546337/ (accessed on 28 June 2021). [CrossRef] [PubMed]

31. Fatemi, S.H.; Folsom, T.D. The neurodevelopmental hypothesis of Schizophrenia, revisited. Schizophr. Bull. 2009, 35, 528-548. Available online: https:/ / pubmed.ncbi.nlm.nih.gov/19223657/ (accessed on 28 June 2021). [CrossRef]

32. Feinberg, I. Schizophrenia: Caused by a fault in programmed synaptic elimination during adolescence? J. Psychiatr. Res. 1982, 17, 319-334. Available online: https:/ / pubmed.ncbi.nlm.nih.gov/7187776/ (accessed on 28 June 2021). [CrossRef] 
33. McGlashan, T.H.; Hoffman, R.E. Schizophrenia as a disorder of developmentally reduced synaptic connectivity. Archives of General Psychiatry. Am. Med. Assoc. 2000, 57, 637-648. Available online: https:// pubmed.ncbi.nlm.nih.gov/10891034/ (accessed on 28 June 2021).

34. Wellman, C.L. Dendritic reorganization in pyramidal neurons in medial prefrontal cortex after chronic corticosterone administration. J. Neurobiol. 2001, 49, 245-253. Available online: https:/ / pubmed.ncbi.nlm.nih.gov/11745662/ (accessed on 29 June 2021). [CrossRef]

35. Walker, E.; Mittal, V.; Tessner, K. Stress and the hypothalamic pituitary adrenal axis in the developmental course of schizophrenia. Annu. Rev. Clin. Psychol. 2008, 4, 189-216. Available online: https:/ / pubmed.ncbi.nlm.nih.gov/18370616/ (accessed on 29 June 2021). [CrossRef] [PubMed]

36. Monteleone, P.; Di Filippo, C.; Fabrazzo, M.; Milano, W.; Martiadis, V.; Corrivetti, G.; Monteleone, A.M.; Maj, M. Flattened cortisol awakening response in chronic patients with schizophrenia onset after cannabis exposure. Psychiatry Res. 2014, 215, 263-267. Available online: https:/ / pubmed.ncbi.nlm.nih.gov/24388728/ (accessed on 29 June 2021). [CrossRef]

37. Manrique-Garcia, E.; Zammit, S.; Dalman, C.; Hemmingsson, T.; Andreasson, S.; Allebeck, P. Cannabis, schizophrenia and other non-affective psychoses: 35 years of follow-up of a population-based cohort. Psychol. Med. 2012, 42, 1321-1328. Available online: https:/ / pubmed.ncbi.nlm.nih.gov/21999906/ (accessed on 29 June 2021). [CrossRef] [PubMed]

38. Donoghue, K.; Doody, G.A.; Murray, R.M.; Jones, P.B.; Morgan, C.; Dazzan, P.; Hart, J.; Mazzoncini, R.; MacCabe, J.H. Cannabis use, gender and age of onset of schizophrenia: Data from the ÆSOP study. Psychiatry Res. 2014, 215, 528-532. Available online: https:/ / pubmed.ncbi.nlm.nih.gov/24461684/ (accessed on 29 June 2021). [CrossRef] [PubMed]

39. Green, M.J.; Chia, T.Y.; Cairns, M.J.; Wu, J.; Tooney, P.A.; Scott, R.J.; Carr, V.J. Catechol-O-methyltransferase (COMT) genotype moderates the effects of childhood trauma on cognition and symptoms in schizophrenia. J. Psychiatr. Res. 2014, $49,43-50$. Available online: https:// pubmed.ncbi.nlm.nih.gov/24252819/ (accessed on 29 June 2021). [CrossRef] [PubMed]

40. Şahin, S.; Yüksel, Ç.; Güler, J.; Karadayi, G.; Akturan, E.; Göde, E.; Özhan, A.A.; Üçok, A. The history of childhood trauma among individuals with ultra high risk for psychosis is as common as among patients with first-episode schizophrenia. Early Interv. Psychiatry 2013, 7, 414-420. Available online: https:/ / pubmed.ncbi.nlm.nih.gov/23343404/ (accessed on 29 June 2021). [CrossRef]

41. Cohen, C.I.; Palekar, N.; Barker, J.; Ramirez, P.M. The relationship between trauma and clinical outcome variables among older adults with schizophrenia spectrum disorders. Am. J. Geriatr. Psychiatry 2012, 20, 408-415. Available online: https: / / pubmed.ncbi.nlm.nih.gov/21427561/ (accessed on 29 June 2021). [CrossRef]

42. Li, D.; Law, S.; Andermann, L. Association between degrees of social defeat and themes of delusion in patients with schizophrenia from immigrant and ethnic minority backgrounds. Transcult. Psychiatry 2012, 49, 735-749. Available online: https:/ / pubmed. ncbi.nlm.nih.gov/23138195/ (accessed on 29 June 2021). [CrossRef]

43. Tandon, R.; Nasrallah, H.A.; Keshavan, M.S. Schizophrenia, "just the facts" 4. Clinical features and conceptualization. Schizophrenia Research. Schizophr. Res. 2009, 110, 1-23. Available online: https://pubmed.ncbi.nlm.nih.gov/19328655/ (accessed on 29 June 2021). [CrossRef]

44. Keshavan, M.S.; Tandon, R.; Boutros, N.N.; Nasrallah, H.A. Schizophrenia, "just the facts": What we know in 2008. Part 3: Neurobiology. Schizophr. Res. 2008, 106, 89-107. Available online: https://pubmed.ncbi.nlm.nih.gov/18799287/ (accessed on 29 June 2021). [PubMed]

45. Crow, T.J. Molecular pathology of schizophrenia: More than one disease process? Br. Med. J. 1980, 280, 66-68. Available online: https:/ / pubmed.ncbi.nlm.nih.gov/6101544/ (accessed on 29 June 2021). [CrossRef] [PubMed]

46. Andreasen, N.C. Negative Symptoms in Schizophrenia: Definition and Reliability. Arch. Gen. Psychiatry 1982, 39, 84-88. Available online: https: / pubmed.ncbi.nlm.nih.gov/7165477/ (accessed on 30 June 2021). [CrossRef] [PubMed]

47. Carpenter, W.T.; Heinrichs, D.W.; Wagman, A.M.I. Deficit and nondeficit forms of schizophrenia: The concept. Am. J. Psychiatry. 1988, 145, 578-583. Available online: https:/ / pubmed.ncbi.nlm.nih.gov/3358462/ (accessed on 30 June 2021). [PubMed]

48. Kirkpatrick, B.; Fenton, W.S.; Carpenter, W.T.; Marder, S.R. The NIMH-MATRICS consensus statement on negative symptoms. Schizophr. Bull. 2006, 32, 214-219. Available online: https://pubmed.ncbi.nlm.nih.gov/16481659/ (accessed on 30 June 2021). [CrossRef] [PubMed]

49. Erhart, S.M.; Marder, S.R.; Carpenter, W.T. Treatment of schizophrenia negative symptoms: Future prospects. Schizophr. Bull. 2006, 32, 234-237. Available online: https:/ / pubmed.ncbi.nlm.nih.gov/16492797/ (accessed on 30 June 2021). [CrossRef] [PubMed]

50. Stahl, S.M.; Buckley, P.F. Negative symptoms of schizophrenia: A problem that will not go away. Acta Psychiatr. Scand. 2007, 115, 4-11. Available online: https:/ / pubmed.ncbi.nlm.nih.gov/17201860/ (accessed on 30 June 2021). [CrossRef]

51. Andreasen, N.C. Thought, Language, and Communication Disorders: I. Clinical Assessment, Definition of Terms, and Evaluation of Their Reliability. Arch. Gen. Psychiatry 1979, 36, 1315-1321. Available online: https://pubmed.ncbi.nlm.nih.gov/496551/ (accessed on 30 June 2021). [CrossRef]

52. Bartels, S.J.; Drake, R.E. Depressive symptoms in schizophrenia: Comprehensive differential diagnosis. Compr. Psychiatry 1988, 29, 467-483. Available online: https://pubmed.ncbi.nlm.nih.gov/3053027/ (accessed on 30 June 2021). [CrossRef]

53. Sands, J.R.; Harrow, M. Depression during the longitudinal course of schizophrenia. Schizophr. Bull. 1999, 25, 157-171. Available online: https: / pubmed.ncbi.nlm.nih.gov /10098919/ (accessed on 30 June 2021). [CrossRef] 
54. Conley, R.R.; Ascher-Svanum, H.; Zhu, B.; Faries, D.E.; Kinon, B.J. The burden of depressive symptoms in the long-term treatment of patients with schizophrenia. Schizophr. Res. 2007, 90, 186-197. Available online: https://pubmed.ncbi.nlm.nih.gov/17110087/ (accessed on 30 June 2021). [CrossRef]

55. Potvin, S.; Sepehry, A.A.; Stip, E. Meta-analysis of depressive symptoms in dual-diagnosis schizophrenia. Aust. N. Z. J. Psychiatry 2007, 41, 792-799. Available online: https:/ / pubmed.ncbi.nlm.nih.gov/17828652/ (accessed on 30 June 2021). [CrossRef]

56. Saykin, A.J.; Gur, R.C.; Gur, R.E.; Mozley, P.D.; Mozley, L.H.; Resnick, S.M.; Kester, D.B.; Stafiniak, P. Neuropsychological Function in Schizophrenia: Selective Impairment in Memory and Learning. Arch. Gen. Psychiatry 1991, 48, 618-624. Available online: https:/ / pubmed.ncbi.nlm.nih.gov/2069492/ (accessed on 30 June 2021). [CrossRef] [PubMed]

57. Keefe, R.S.E.; Eesley, C.E.; Poe, M.P. Defining a cognitive function decrement in schizophrenia. Biol. Psychiatry. 2005, 57, 688-691. Available online: https://pubmed.ncbi.nlm.nih.gov/15780858/ (accessed on 30 June 2021). [CrossRef] [PubMed]

58. Aleman, A.; Hijman, R.; De Haan, E.H.F.; Kahn, R.S. Memory impairment in schizophrenia: A meta-analysis. Am. J. Psychiatry 1999, 156, 1358-1366. Available online: https:/ / pubmed.ncbi.nlm.nih.gov/10484945/ (accessed on 30 June 2021). [PubMed]

59. Achim, A.M.; Lepage, M. Episodic memory-related activation in schizophrenia: Meta-analysis. British Journal of Psychiatry. Br. J. Psychiatry 2005, 187, 500-509. Available online: https:/ / pubmed.ncbi.nlm.nih.gov/16319401/ (accessed on 1 June 2021). [CrossRef] [PubMed]

60. Ranganath, C.; Minzenberg, M.J.; Ragland, J.D. The Cognitive Neuroscience of Memory Function and Dysfunction in Schizophrenia. Biol. Psychiatry 2008, 64, 18-25. Available online: https:/ / pubmed.ncbi.nlm.nih.gov/18495087/ (accessed on 1 June 2021). [CrossRef]

61. Dickinson, D.; Ramsey, M.E.; Gold, J.M. Overlooking the obvious: A meta-analytic comparison of digit symbol coding tasks and other cognitive measures in schizophrenia. Arch. Gen. Psychiatry 2007, 64, 532-542. Available online: https://pubmed.ncbi.nlm. nih.gov /17485605/ (accessed on 1 June 2021). [CrossRef] [PubMed]

62. Henry, J.D.; Crawford, J.R. A meta-analytic review of verbal fluency deficits in schizophrenia relative to other neurocognitive deficits. Cogn. Neuropsychiatry 2005, 10, 1-33. Available online: https://pubmed.ncbi.nlm.nih.gov/16571449/ (accessed on 1 June 2021). [CrossRef]

63. Orzack, M.H.; Kornetsky, C. Attention Dysfunction in Chronic Schizophrenia. Arch. Gen. Psychiatry 1966, 14, 323-326. Available online: https: / / pubmed.ncbi.nlm.nih.gov/5903423/ (accessed on 1 June 2021). [CrossRef]

64. Fioravanti, M.; Carlone, O.; Vitale, B.; Cinti, M.E.; Clare, L. A meta-analysis of cognitive deficits in adults with a diagnosis of schizophrenia. Neuropsychol. Rev. 2005, 15, 73-95. Available online: https:/ / pubmed.ncbi.nlm.nih.gov/16211467/ (accessed on 1 June 2021). [CrossRef] [PubMed]

65. Laws, K.R. A meta-analytic review of Wisconsin card sort studies in schizophrenia: General intellectual deficit in disguise? Psychology 1999, 4, 1-30. Available online: https:/ / pubmed.ncbi.nlm.nih.gov/16571497/ (accessed on 1 June 2021). [CrossRef]

66. Lee, J.; Park, S. Working memory impairments in schizophrenia: A meta-analysis. J. Abnorm. Psychol. 2005, 114, 599-611. Available online: https: / / pubmed.ncbi.nlm.nih.gov /16351383/ (accessed on 1 June 2021). [CrossRef]

67. Reichenberg, A.; Harvey, P.D. Neuropsychological Impairments in Schizophrenia: Integration of Performance-Based and Brain Imaging Findings. Psychol. Bull. 2007, 133, 33-58. Available online: https:// pubmed.ncbi.nlm.nih.gov/17723032/ (accessed on 1 June 2021). [CrossRef] [PubMed]

68. Barch, D.M.; Smith, E. The Cognitive Neuroscience of Working Memory: Relevance to CNTRICS and Schizophrenia. Biol. Psychiatry 2008, 64, 11-17. Available online: https:/ / pubmed.ncbi.nlm.nih.gov/18400207/ (accessed on 1 June 2021). [CrossRef] [PubMed]

69. Hard, M.L.; Mills, R.J.; Sadler, B.M.; Turncliff, R.Z.; Citrome, L. Aripiprazole lauroxil: Pharmacokinetic profile of this longacting injectable antipsychotic in persons with schizophrenia. J. Clin. Psychopharmacol. 2017, 37, 289-295. Available online: https: / / www.ncbi.nlm.nih.gov/pmc/articles/PMC5400404/ (accessed on 1 June 2021). [CrossRef]

70. Stępnicki, P.; Kondej, M.; Kaczor, A.A. Current concepts and treatments of schizophrenia. Molecules 2018, 23, 2087. [CrossRef] [PubMed]

71. Miyamoto, S.; Miyake, N.; Jarskog, L.F.; Fleischhacker, W.W.; Lieberman, J.A. Pharmacological treatment of schizophrenia: A critical review of the pharmacology and clinical effects of current and future therapeutic agents. Mol. Psychiatry 2012, 17, 1206-1227. [CrossRef]

72. Komatsu, H.; Fukuchi, M.; Habata, Y. Potential utility of biased GPCR signaling for treatment of psychiatric disorders. Int. J. Mol. Sci. 2019, 20, 3207. [CrossRef]

73. Missale, C.; Russel Nash, S.; Robinson, S.W.; Jaber, M.; Caron, M.G. Dopamine receptors: From structure to function. Physiol. Rev. 1998, 78, 189-225. [CrossRef]

74. Tiihonen, J.; Mittendorfer-Rutz, E.; Majak, M.; Mehtälä, J.; Hoti, F.; Jedenius, E.; Enkusson, D.; Leval, A.; Sermon, J.; Tanskanen, A.; et al. Real-world effectiveness of antipsychotic treatments in a nationwide cohort of 29,823 patients with schizophrenia. JAMA Psychiatry 2017, 74, 686-693. [CrossRef]

75. Miyamoto, S.; Duncan, G.E.; Marx, C.E.; Lieberman, J.A. Treatments for schizophrenia: A critical review of pharmacology and mechanisms of action of antipsychotic drugs. Mol. Psychiatry 2005, 10, 79-104. [CrossRef]

76. Fellner, C. Pharmaceutical Approval Update. Pharm. Ther. 2015, 40, 807-808.

77. Federal Drug Administration. Aristada Drug Insert. 1998; 50, pp. 1-25.

78. Federal Drug Administration. Abilify Drug Insert Interactions. 2002; 50, pp. 1-25. 
79. Hard, M.L.; Wehr, A.Y.; Sadler, B.M.; Mills, R.J.; von Moltke, L. Population Pharmacokinetic Analysis and Model-Based Simulations of Aripiprazole for a 1-Day Initiation Regimen for the Long-Acting Antipsychotic Aripiprazole Lauroxil. Eur. J. Drug Metab. Pharmacokinet. 2018, 43, 61-69. [CrossRef]

80. Raedler, L.A. Aripiprazole Lauroxil (Aristada): Long-Acting Atypical Antipsychotic Injection Approved for the Treatment of Patients with Schizophrenia. Am. Health Drug Benefits 2016, 9, 40-43.

81. Rohde, M.; MØrk, N.; Håkansson, A.E.; Jensen, K.G.; Pedersen, H.; Dige, T.; Erling, B.J.; Holm, R. Biological conversion ofaripiprazole lauroxil-An N-acyloxymethyl aripiprazole prodrug. Results Pharma Sci. 2014, 4, 19-25. [CrossRef]

82. Allen, J.A.; Yost, J.M.; Setola, V.; Chen, X.; Sassano, M.F.; Chen, M.; Peterson, S.; Yadav, P.N.; Huang, X.-P.; Feng, B.; et al. Discovery of $\beta$-arrestin-biased dopamine D 2 ligands for probing signal transduction pathways essential for antipsychotic efficacy. Proc. Natl. Acad. Sci. USA 2011, 108, 18488-18493. [CrossRef] [PubMed]

83. Cruz, M.P. Aripiprazole lauroxil (Aristada): An extended-release, long-acting injection for the treatment of schizophrenia. Pharm. Ther. 2016, 41, 556.

84. Hard, M.L.; Mills, R.J.; Sadler, B.M.; Wehr, A.Y.; Weiden, P.J.; von Moltke, L. Pharmacokinetic Profile of a 2-Month Dose Regimen of Aripiprazole Lauroxil: A Phase I Study and a Population Pharmacokinetic Model. CNS Drugs 2017, 31, 617-624. [CrossRef] [PubMed]

85. Turncliff, R.; Hard, M.; Du, Y.; Risinger, R.; Ehrich, E.W. Relative bioavailability and safety of aripiprazole lauroxil, a novel once-monthly, long-acting injectable atypical antipsychotic, following deltoid and gluteal administration in adult subjects with schizophrenia. Schizophr. Res. 2014, 159, 404-410. [CrossRef]

86. Weiden, P.J.; Du, Y.; von Moltke, L.; Wehr, A.; Hard, M.; Marandi, M.; Walling, D.P. Pharmacokinetics, Safety, and Tolerability of a 2-Month Dose Interval Regimen of the Long-Acting Injectable Antipsychotic Aripiprazole Lauroxil: Results From a 44-Week Phase I Study. CNS Drugs. 2020, 31, 7. [CrossRef]

87. Meltzer, H.Y.; Risinger, R.; Nasrallah, H.A.; Du, Y.; Zummo, J.; Corey, L.; Bose, A.; Stankovic, S.; Silverman, B.L.; Ehrich, E.W. A randomized, double-blind, placebo-controlled trial of aripiprazole lauroxil in acute exacerbation of schizophrenia. J. Clin. Psychiatry 2015, 76, 085-090. [CrossRef]

88. Nasrallah, H.A.; Aquila, R.; Stanford, A.D.; Jamal, H.H.; Weiden, P.J.; Risinger, R. Metabolic and endocrine profiles during 1-year treatment of outpatients with schizophrenia with aripiprazole lauroxil. Psychopharmacol. Bull. 2017, 47, 35-43. [PubMed]

89. Miller, B.J.; Claxton, A.; Du, Y.; Weiden, P.J.; Potkin, S.G. Switching patients with schizophrenia from paliperidone palmitate to aripiprazole lauroxil: A 6-month, prospective, open-label study. Schizophr. Res. 2019, 208, 44-48. [CrossRef] [PubMed]

90. Potkin, S.G.; Risinger, R.; Du, Y.; Zummo, J.; Bose, A.; Silverman, B.; Stankovic, S.; Ehrich, E. Efficacy and safety of aripiprazole lauroxil in schizophrenic patients presenting with severe psychotic symptoms during an acute exacerbation. Schizophr. Res. 2017, 190, 115-120. [CrossRef] [PubMed]

91. Targum, S.D.; Risinger, R.; Du, Y.; Pendergrass, J.C.; Jamal, H.H.; Silverman, B.L. Effect of patient age on treatment response in a study of the acute exacerbation of psychosis in schizophrenia. Schizophr. Res. 2017, 179, 64-69. [CrossRef] [PubMed]

92. Correll, C.U.; Stanford, A.D.; Claxton, A.; Du, Y.; Weiden, P.J. Social and functional outcomes with two doses of aripiprazole lauroxil vs placebo in patients with schizophrenia: A post-hoc analysis of a 12-week phase 3 efficacy study. Psychiatry Res. 2019, 274, 176-181. [CrossRef] [PubMed]

93. Citrome, L.; Du, Y.; Weiden, P.J. Assessing effectiveness of aripiprazole lauroxil vs placebo for the treatment of schizophrenia using number needed to treat and number needed to harm. Neuropsychiatr. Dis. Treat. 2019, 15, 2639-2646. [CrossRef]

94. Nasrallah, H.A.; Newcomer, J.W.; Risinger, R.; Du, Y.; Zummo, J.; Bose, A.; Stankovic, S.; Silverman, B.L.; Ehrich, E.W. Effect of Aripiprazole Lauroxil on Metabolic and Endocrine Profiles and Related Safety Considerations Among Patients With Acute Schizophrenia. J. Clin. Psychiatry 2016, 77, 1519-1525. [CrossRef]

95. Citrome, L.; Du, Y.; Risinger, R.; Stankovic, S.; Claxton, A.; Zummo, J.; Bose, A.; Silverman, B.L.; Ehrich, E.W. Effect of aripiprazole lauroxil on agitation and hostility in patients with schizophrenia. Int. Clin. Psychopharmacol. 2016, 31, 69-75. [CrossRef]

96. McEvoy, J.P.; Risinger, R.; Mykhnyak, S.; Du, Y.; Liu, C.-C.; Stanford, A.D.; Weiden, P.J. Durability of Therapeutic Response With Long-Term Aripiprazole Lauroxil Treatment Following Successful Resolution of an Acute Episode of Schizophrenia. J. Clin. Psychiatry 2017, 78, 1103-1109. [CrossRef]

97. Peters, L.; Krogmann, A.; von Hardenberg, L.; Bödeker, K.; Nöhles, V.B.; Correll, C.U. Long-Acting Injections in Schizophrenia: A 3-Year Update on Randomized Controlled Trials Published January 2016-March 2019. Curr. Psychiatry Rep. $2019,21,12$. [CrossRef] [PubMed]

98. Cameron, C.; Zummo, J.; Desai, D.N.; Drake, C.; Hutton, B.; Kotb, A.; Weiden, P.J. Aripiprazole Lauroxil Compared with Paliperidone Palmitate in Patients with Schizophrenia: An Indirect Treatment Comparison. Value Health 2017, $20,876-885$. [CrossRef] [PubMed]

99. Salzman, P.M.; Raoufinia, A.; Legacy, S.; Such, P.; Eramo, A. Plasma concentrations and dosing of 2 long-acting injectable formulations of aripiprazole. Neuropsychiatr. Dis. Treat. 2017, 13, 1125-1129. [CrossRef] [PubMed] 